\title{
GRIEKS AAN DIE P.U. VIR C.H.O.*
}

Met hierdie rede word betoog dat die patroon van die studie van Grieks wat deur die Atheners vier tot vyf eeue v.C. daargestel is en deur die Alexandryne en Pergamon van drie eeue v.C. tot drie eeu n.C. verder gevorm is, deur die eeue nagevolg is, telkens met die oogmerke wat gepas het by die bepaalde tye, tot in die twintigste eeu. Volgens hierdie patroon is Attiese Grieks bestudeer. Die Attiese Grieks is die literêre taal, die skryftaal, van Athene in die vyfde en vierde eeue v.C. Hierdie tradisie is ook aan die P.U. vir C.H.O. nagevolg. Aan hierdie Universiteit is die studente van Grieks hoofsaaklik, indien nie uitsluitlik nie, voornemende teologiese studente.

Die taal waarin die N.T. egter geskryl is, nl. die spreektaal in die tyd van Christus, was die Koinê of Hellenistiese Grieks. Daarom word hier betoog dat die studie van Grieks as voorbereiding van die teologiese student die Koinê as uitgangspunt moet hê en nie Atties nie.

Om teenswoordige situasies te begryp en te waardeer en 'n toekomsperspektief te kry, is dit noodsaaklik dat die verlede ondersoek, oorskou en waardeer moet word.

Daarom is dit nodig om ' $n$ historiese oorsig te gee om daaruit riglyne te trek vir die toekoms. Met so 'n onderwerp moet noodwendig heelwat bekende feite gegee word ter wille van die eenheidsbeeld. Hierdie rede wil gevolglik nie nuwe feitlike bydraes gee nie, maar die bekende feite sodanig rangskik dat daaruit die gepaste afleidings gemaak kan word vir die beoefening van die vak aan hierdie Universiteit.

Ter wille van die lede van die gehoor wat nie opleiding van die Klassieke ontvang het nie sal belangrike terme telkens nader verklaar word.

1. Die eerste Griekse studies is gerig op die verstaan, vertolking en waardering van die werke van Griekse digters, veral die gedigte van Homeros. Onder die Atheense geleerdes voor 300 v.C., was een van die oogmerke van die studie om die dieper betekenis van die inhoud van die gedigte, terme en name agter te kom en só uit te lê dat die teenstrydigheid tussen die gedigte en die wetenskaplike opvattings van hulle tyd met mekaar versoen kon word. Dit was 'n eties-godsdienstige

* Inougurele rede, gelewer op 16 Junie 1967, by die aanvaarding van 'n professoraat in Grieks, aan die P.U. vir C.H.O 
doelstelling. ' $n$ Tweede doel van die studie was 'n eties-godsdienstige doelstelling. ' $n$ Tweede doel van die studie was 'n estetiese, nl. om die skoonheid van die gedigte te waardeer en te geniet. 'n Derde doelstelling was om die betowerende krag van die woord te bemeester ter wille van die oorredingskuns. Eersgenoemde doelstelling het hoofsaaklik gegaan om die inhoud en die tweede en derde om die vorm. Eersgenoemde kan gesien word as logikale en die tweede en derde as leksikale beoefening. Met logikaal word bedoel die aspek van die studie wat hom bepaal by die feitlikheid, rangskikking en vertolking van die inhoud; met leksikaal word bedoel die aspek wat handel oor die keuse, rangskikking en voordrag van die woord.

So vroeg as die sesde eeu v.C. het Griekse wetenskaplikes in en buite Athene, die sg. natuurfilosowe, gesoek na wetenskaplike verklarings, of verklarings wat met die rede begryp kon word, van die oorsprong, bestaan en bestemming van die wêreld met sy verskynsels. Die wetenskaplikes wou die probleme van hulle tyd rasioneel benader; hulle wou logikale verklaringe bied. Die mediese skool van Hippokrates benader die mediese gevalle positief empiries wetenskaplik, Thucydides plaas geskiedskrywing op wetenskaplike voet en Sokrates kon sê kennis is deug; hy kon ook gesê het verstandelike of logikale kennis is deug. Hierdie deug was die kuns om as „kaloskagathos" ('n heer, 'n ,gentleman") tot die hoogste voordeel van die staat, en daardeur van sigself, te lewe in geregtigheid, verstandigheid en selfbeheersing, gegrond op die kennis van waarheid, heiligheid, skoonheid en goedheid. Plato bied 'n wetenskaplik logies-ontologiese filosofie en Aristoteles 'n empiries logiese sisteem.

Die Atheners het in hulle opvoeding gestreef na die vrye harmonieuse ontwikkeling van die mens as staatsburger eerder as na beroepskundige en tegniese opleiding; eerder na tcoretiese kennis as praktiese kundigheid. Die opvoeding was esteties, eties, intellektualisties antroposentries; die mens staan in die middelpunt van die belangstelling. Die vakke aan die Atheense skool was lees, skryf, reken, sang, musiek, voordrag en gimnastiek. Dịt was die gewone laer of basiese onderrig. Die kinders wat geld en tyd gehad het, kon dan nog, om 'n kaloskagathos, 'n heer, in die demokratiese Athene, te wees, opleiding in retoriek ondergaan wat teen betaling deur die Sofiste aangebied is. Die opleiding in retoriek, redenaarskuns, het die gesiene heer in staat gestel om toesprake te maak op 
die volksvergadering. Verskillende redenaars en Sofiste het meegedoen aan die ontwikkeling van die retoriek; Plato wou die retoriek dialekties rasioneel fundeer. Aristoteles skryf drie boeke daaroor, waarin hy die kuns empiries-logikaal behandel. Hierdie werk van Aristoteles het sy deurwerking tot in die moderne tye.

Kort gestel, die Atheense skool het veral drie dissiplines beoefen, nl. logika, retoriek en digkuns. Hierdie studies moes die mens opvoed en veredel eerder as oplei tot groot wetenskaplike.

2. Na 300 v.C. het Alexandrië in Egipte die plek van Athene ingeneem as litterêre sentrum van die wêreld. Die eintlike klassieke Griekse geleerdheid begin in hierdie tyd. Met die Griekse taal word hier hoofsaaklik bedoel die Atheense dialek; Griekeland was nie een verenigde staat met 'n homogene volk nie, maar die Griekse onafhanklike stadstate en eilandstate het verspreid gelê van Sicilië en Suid-Italië aan die westekant tot aan die weskus van Klein-Asië aan die oostekant.

Drie hoofdialekte is gepraat, nl. Ionies, Dories en Aiolies. Onder elk van die drie hoofdialekte was weer talle dialekte wat onderling van mekaar verskil het. Die Atheense dialek was in hoofsaak Ionies. Waar hier van die Atheense dialek gepraat word, word hoofsaaklik bedoel die skryftaal as kunstaal van Athene in die vyfde en vierde eeu v.C. in onderskeid van die algemene spreektaal. Die Griekse skrywers van die ou tyd het hoofsaaklik hierdie skryftaal gebruik, wat bekend geword het as Klassieke Grieks.

Geleerdes van Alexandrië, met al sy professioneles, gee veral aandag aan die digkuns en grammatika. Uit hierdie tyd dateer baie kommentare, bekend as die Scholia, oor die werke van Griekse skrywers, onder wie veral Homeros en die dramaturge van belang was. Hierdie geleerdheid was soos Sandys in sy boek „A History of Classical Scholarship" dit stel „a study of verbal criticism". In hierdie tyd ontstaan die begeerte om weer suiwer Atties, die Atheense skryftaal van die vyfde en vierde eeue v.C., te skryf - die strewe word genoem die Attisisme.

In Pergamom in Klein-Asië is in hierdie tyd, d.w.s. omtrent drie eeue voor Christus, tot sewe n.C., 'n groter verskeidenheid nagestreef. Die geleerdheid het kuns, inskripsies, topografie, chronologie, die filosofie van die Stoa, letterkundige kritiek en grammatika omvat. 
Die geleerdheid in die kosmopolitaanse stad Pergamom was eg Helleens, hoofsaaklik Atheens. Hellas is 'n ander woord vir Griekeland en Helleens beteken Grieks. Die ou Akademie van Plato, die Atheense wysgeer, is in Pergamom voortgesit. Die aspekte van die Atheense geleerdheid wat hier die aandag ontvang het was logika en reotriek. Die Stoïsynse wysgere het hulle in Pergamom gevestig en logika en retoriek bestudeer.

Athene het ook nog bly voortbestaan as opvoedkundige sentrum met belangstelling veral vir filosofie, die nuwe komedie en geskiedskrywing. Ook op die Griekse eiland Rhodos het sodanige skool bestaan. By al hierdie sentra het biblioteke ontstaan. Ook die Siriese hoofstad Antiochië het 'n biblioteek gehad. Selfs daar is Grieks geleer.

Die Griekse ideaal van beskaafde gebalanseerde politieke menswees, met waardes van skoonheid, goedheid, geregtigheid, waarheid, selfbeheersing, verstandigheid, verfyndheid en wetenskaplike filosofiese kennis het die wêreld sodanig beïndruk dat almal die Griekse manier van doen nagestreef het. Grieks was die wêreldtaal in die tyd toe Christus gebore is.

Hierdie neiging van die ander volke om volgens die Griekse, hoofsaaklik Atheense, manier van doen te lewe word die Hellenisme genoem. Die ander volke het nie Grieke, Hellene, geword nie, maar hulle kultuur het Hellenisties geword, hulle het groot Griekse invloed vertoon.

3. Ook die Romeine het die Griekse kultuur bewonder en nagevolg. Hierdie stelling behoef geen verdere betoog nie.

Selfs die Romeinse skrywers wat gekant was teen die navolging van en oornames uit die Griekse letterkunde toon Griekse invloed. Teenstanders van die navolging van Grieks soos Cato en selfs Cicero het self Grieks geleer en die Grieks wat hulle geleer het, was die literêre Atties. Caesar het retoriek in Rhodos geleer, Vergilius het Theokritos nagevolg en Horatius vir Archilochos. Varro, die jonger Seneca, Plinius, Probus en Quintilianus studeer almal Grieks.

Behalwe die navolging van die digters het die Romeine veral belang gestel in die retoriek.

Selfs Christene in die Romeinse tyd wat gekant was teen die studie van Grieks, skryf in Grieks. So kan die name van Clemens van Alexandrië, Origines, Eusebius, Johannes Chrysostomus e.a. genoem word. Die eerste biskoppe in Rome was Griekssprekenf. Die eerste Latynssprekende biskop in Rome 
was eers Victor I in c. 189 n.C. Die teëkanting van Christene teen die studie van Grieks was egter nie soseer teen die studie van die logika, retoriek en grammatika as teen die mitologie en filosofie nie.

Met die sluiting van die Atheense skool deur Justinianus in 529 n.C. word die heidense bestudering van Grieks eintlik tot stilstand gebring, sodat feitlik die enigste studie van Grieks in die Weste verder deur geestelikes van die Christelike kerk gedoen is.

Selfs 'n man soos Augustinus, einde vyfde eeu n.C., het Grieks geleer. Augustinus stel hom op die standpunt dat die Here die heidense wysgere skatte van wysheid laat ontwikkel het ten behoewe van die kerk, soos die Egiptenare skatte van goud en silwer gemaak het om aan Israel te gee.

Die dissiplines wat veral beoefen is, was logika, retoriek en grammatika, volgens die besondere doel van elkeen se behoeftes. By die Christene: ter wille van die verstaan en uitleg van die Skrif, ter wille van preektegnieke en voordrag, asook ter wille van die verweer teen die paganisme.

Met die verdeling van die Romeinse Ryk (395 n.C.) in die twee dele tussen die twee seuns van Theodosius, nl. Arcadius in Bisantium en Honorius in Rome, skei ook die kerk in twee dele. Hierna is die studie van Grieks in Bisantinum of Konstantinopel lank volgehou, maar in Rome is Grieks deur Latyn verdring. Claudianus was die laaste groot verteenwoordiger van die paganisme wat Rome en Milaan besoek het, al was hy nominaal 'n Christen.

4. Die Middeleeue begin met die oorname van die wêreldmag deur die Nordiese of Germanse volke in die sesde eeu n.C. Die Germane breek feitlik alles af, maar die kerk bly staan. Die kerk word die organiseerder, oorwinnaar en, deur die monnikedom, die opvoeder van almal en die medium is Latyn. God staan in die middelpunt van die hele lewe die Christelike godsdiens was staatsgodsdiens.

Die monnike in die kloosters word die bewaarders van die antieke geleerdheid, maar feitlik alles word in Latyn vertaal en geleer. Ook die grammatika, retoriek en logika, van Griekse oorsprong, word in Latynse grammatikaskole onderrig in Latyn.

So vroeg as die sesde eeu n.C. is daar tekens van 'n Griekse geleerdheid in Spanje, in die sewende eeu in Frankryk, Ierland en Engeland en in die agtste eeu geringe tekens 
in Duitsland; terwyl die reste van 'n Griekse geleerdheid feitlik deurentyd in Italië bewaar is.

In die tyd na Karel die Grote in die agtste eeu n.C. begin die verskillende skole, Hofskole, Kloosterskole, Domskole, Stiftskole en Parogie- of kosterskole. Dié skole was kerklike instellings of is deur die kerk beheer en die leergange was die trivium: grammatika, retoriek en logika, opgevolg deur die quadrium: rekene, astronomie, geometrie en sang.

Die karakter van Griekse studies in die sg. Middeleeue is gekenmerk deur mistieke en allegoriese interpretasies (Baldry, p. 5).

Grammatika was Latynse grammatika en moes geleer word om goeie taal te kan gebruik en die Bybel in Latyn te kan lees en verklaar. Retoriek is beoefen om die figuurlike Bybeltaal te verstaan, briewe en oorkonde te skryf en te preek. Logika moes mens leer om die gedagtes reg uit te druk en argumente op te stel om ketters en heidene te bestry. Die rekene en astronomie het gedien om die Christelike feestye te bereken, geometrie vir kerkbou, en sang vir die erediens.

Die ou Atheense patroon van logika, retoriek en grammatika word dus steeds voortgesit, maar toegepas op die eise van hulle doel.

In die tiende eeu n.C. het Noormanne die westelike Europa verower, die More was doenig in Suid-Europa en die Magjare in Duitsland.

$\mathrm{Na}$ die verdrywing van die More en die Magjare is die inherente krag van die ou oorgelewerde beskawing gestimuleer cleur die soeke van Arabiese geleerdes na kennis. Hierdie Arabiese geleerdes het in hulle soeke na geleerdheid teruggegaan na die ou Klassieke bronne, nl. werke van Ptolemeus, Euclides, Galenus, Hippocrates en Aristoteles. Kennis van Griekse literatuur in hierdie tyd in Wes-Europa, kom van Latynse vertalings van Arabiese vertalings van die oorspronklike Grieks. Saam met hierdie Saraseense (Moslemse) geleerdheid val die ontstaan van die skolastiek, 'n reproduksie van die Griekse filosofie onder beheer van die dogma van die kerk.

'n Nuwe organisasie van stede en volke ontstaan, wat naas die sedelik-godsdienstige opvoeding ook ' $n$ behoefte gehad het aan suiwer professionele en verstandelike vorming. Stad- of dorpskole ontstaan wat hulle weldra onderskei van klooster- en kerkskole. Twee rigtings is dan in die onderwys onderskeibaar, $\mathrm{nl}$. die prakties-gerigte onderwys en die Latynse 
grammatika-onderrig. Die vakke vir praktiese onderrig was lees, skryf en rekene vir die handel; geskiedenis, aardrykskunde en natuurkennis vir die verkeer. Griekse studie word in hierdie tyd net gedoen deur geestelikes.

5. Renaissance en Humanisme. In dic veertiende eeu n.C. lei die soeke na kennis tot entiesiastiese belangstelling in die Klassieke geleerdheid, eers hoofsaaklik die Latynse geleerdheid, maar weldra ook Grieks, veral toe vele Griekse tekste hulle pad na die Weste vind met die val van Konstantinopel in 1453 n.C. Die herlewing van geleerdheid word genoem die Renaissance.

Die kerk verloor sy sterk dissiplinerende invloed op die mons en 'n nuwe lewens- en geesteshouding ontstaan wat weer die mens, en nie God nie, in die middelpunt van alle menslike belangstelling plaas; die humanisme breek deur op alle terreine. 'n Afkeer ontstaan teen die skolastiek, 'n terugkeer na die Klassieke geleerdheid vind plaas, eintlik na die Atheense Humanisme. Maar ook 'n terugkeer na die Woord van God vind plaas, t.w. in die Hervorming. Die Hervorming het egter nie 'n groot invloed op die studie van Grieks nie. Hoewel Grieks ook deur teoloë geleer is, is steeds die Atheense skryftaal volgens die tradisie geleer.

Die Renaissance begin in die ou Latynse land Italië en versprei oor die hele Europa. In Italië het die humanisme nog 'n aristokratiese karakter, dit kom nog net onder geleerdes voor. In Frankryk brei die humanisme uit na die volk en só sprei dit oor die res van Europa, eers oor Nederland en Engeland en dan ook na Duitsland. Opvoeding is dan nie meer net die voorreg van die geestelikes nie, maar van alle vrye mense. Die universalistiese denkbeelde van die Middeleeue word vervang deur 'n groeiende nasie-besef. Die derde stand tree na vore.

Die eerste vorm van die humanistiese opvoeding was 'n studie van die Klassieke tale en lettere, waarvan die doel was die beheersing van Grieks en Latyn. Hierdie beheersing bestaan in die skryf van Latyn en Grieks volgens die Klassieke styl, wat Grieks betref, korrekte en mooi Atties. Hierdie formalisme word wel deur die realisme in die sestiende eeu teëgewerk, maar die korrekte skrywe van veral Latyn bly lank 'n ideaal.

Die geskiedenis van die Klassieke geleerdheid gedurende die ses eeue na die Renaissance word bepaal deur die volke 
wat agtereenvolgens die leiding op dié gebied geneem het, nl. Italië, Frankryk, Holland, Engeland en Duitsland. Die belangstelling vir die geleerdheid in die Klassieke val saam met die oplewing van humanisme in die betrokke lande.

Die eerste periode is die Italiaanse tydperk van herlewing van geleerdheid, in besonder Klassieke geleerdheid. Die tydperk strek van die dood van Dante 1321 tot die val van Rome in 1527. Die Klassieke geleerdheid het hier 'n sterk formalistiese karakter. Nog 'n kenmerk in hierdie tyd is die nabootsing en reproduksie van Klassieke modelle van styl en lewe. 'n Groot ywer kom voor om Klassieke tekse te vermenigvuldig, ook Griekse tekse, veral na die besoek van Chrysoloras van Konstantinopel in 1395. 'n Ywer om die regte tekslesing vas te stel ontaard in 'n verbalisme. Die Alexandrynse tipe Griekse geleerdheid herleef. Die taal wat bestudeer is was steeds die Atheense skryftaal.

Vername manne uit die tyd is Petrarca (1304-1374), da Feltra (1378-1477) en Agricola (1443-1485). Hulle was ook opvoedkundiges. Die doel van die opvoedkunde in dié tyd was die veredeling van die mens, en hierin speel die Klassieke 'n groot rol.

Die tweede periode is die Franse periode. Die periode begin met die stigting van die College de France deur Francis I in 1530 en strek tot die end van die sewentiende eeu. Dit val dus vir 'n groot deel saam met die Hollands-Engelseperiode.

Groot Klassici uit dié tyd is Scaliger (1540-1609), Casoubon (1559-1614), Lipsius (1547-1606) en Salmasius (1588 $-1653)$.

Hierdie tydperk is die era van die groot veelsydige historici van Frankryk en Nederland. In Frankryk word dit gekenmerk deur ' $h$ veelsydige kennis van mitologie en godsdiens van die oudheid eerder as noukeurige taalstudie. In die agttiende eeu sit Rousseau (1712-1778) hierdie soort studie in Frankryk voort.

Die derde periode, dié van Holland en Engeland, strek van die tweede helfte'van die sewentiende eeu tot die helfte van die agttiende eeu. Geleerdes uit dié tyd is Bentley (16621742), Hemsterhuys (1685-1766), wat ook in die opvoedkunde 'n groot invloed gehad het, Ruhnken (1723-1798) en die Engelsman Porson. Veral in Engeland bestaan die strewe om die mens te veredel. Die Klassieke word voorgeskryf om die mens 
op te voed tot 'n Victoriaanse ,gentleman". Die Engelse openbaar 'n aandagtige eerbied vir die empiriese feitlikheid. Regte Attiese taalgebruik, mooi styl en gepaste idioom word nagestreef. Tekskritiek word beoefen en veral die werke van die digters, redenaars en geskiedskrywers van die Klassieke Athene word gelees. Die ou Atheense en Alexandrynse tipe geleerdheid herleef dus in Engeland. Hierdie is die tyd van kritiek historiese, literêre en veral teks-kritiek waarvoor veral Porson hom beywer het.

Die vierde periode is die Duitse Aufklärung van die agttiende eeu. Op filosofiese gebied het Kant in hierdie tyd groot invloed gehad. Hy tipeer die rasionalisme van die Duitse verligting. Onder die opvoedkundiges, wat die Klassici help voorberei het, moet veral J. B. Basedow (1723-1790), Salzmann (1744-1811) en E. von Rochow (1734-1806) genoem word.

Klassici van naam in hierdie tyd was Wolf (1759-1824); die fundeerder van die Duitse ensiklopediese tipe geleerdheid, die sg. Altertumswissenschaft; Boeckh (1785-1867) met sy historiese en antikwariese skool en G. Hermann, bekend vir sy kritiek, ook tekskritiek, en grammatikale studies.

Die Duitsers was baie produktief. Veral Wolf en Boeckh het veel gedoen vir fundering en vestiging van die metodologie van die Klassieke studie.

Tot hiertoe was die Wes-Europese geleerdheid rasionalisties en meganisties (Schouten, p. 4).

Teen die end van die agttiende eeu kom die belangstelling in die empiriese natuurwetenskappe. Hierdie belangstelling staan bekend as die positivisme en scientisme. Op die gebied van die kunste is hierdie tyd die tyd van die Romantiek.

Hierdie nuwe humanisme bestry egter nie die rasionalistiese-benaderde Alterumswissenschaft nie, maar verdiep dit eerder: die vergelykende taalkunde en gedifferensieerde kultuurkundige studies van die Duitsers is ook resultaat van die stimulus.

Met die aanbreek van die romantiek en oplewing in die wetenskappe verloor die Klassieke, as bron van die natuurwetenskappe, hulle gesag. Hierna is die doel van die Klassieke studies veral opvoedkundig: die mens moet ontwikkel met behulp van Klassieke studies tot volledig gebalanseerde wetenskaplik-denkende mens met hoë etiese waardes. In hierdic tyd word die klassieke studies min of meer internasionaal. Die studie van die Klassieke in die verskillende lande behou 
egter hul onderskeie kenmerke. Dit is egter steeds die Attiese dialek wat geleer word, en die werke van digters, geskiedskrywers, redenaars en Plato word gelees. Dit is nog steeds die Atheense, Alexandrynse en Pergamese tipe geleerdheid.

Italië lewer nie groot bydraes in die agttiende en negentiende eeue nie en Frankryk is vir 'n tyd lank deur politieke onrus geteister.

Die Engelse Klassieke in die agttiende en negentiende eeue word gekenmerk deur 'n belangstelling in en gevoel vir styl, idioom, versmaat en fyn kritiese beoordeling van die teks. Suiwer Atties word geleer en tekskritiek ontaard byna in 'n spel tot plesier van die groot geleerdes. Die studie van antieke geskiedenis, wysbegeerte en kuns het eintlik buite die Klassieke vakgeleerdheid geval. In die negentiende eeu was Klassieke skoling in Engeland 'n essensiële deel van die opvoeding van die klasse wat tyd en geld daarvoor gehad het, soos in die Antieke Athene. ,Training in the Classics was part of the ladder by which the sons of the aristocracy climbed to eminence in the church, in the law, in the civil service. But it was more than this. Classical studies were part of the education of the Victorian gentleman, something which no one who claimed to be a gentleman could do without. Those were the days when most men of note - philosophers, poets, even prime ministers - were good classical scholars" (Baldry).

Hierdie ideaal het ook bly voortleef in die twintigste eeu, maar die Klassieke beklee nou 'n baie beskeier plek in die algemene skoolprogram:

In Holland het Leiden van die begin af die leiding in die studie van die Klassieke geneem. In die agttiende en negentiende eeue het veral Bake en Cobet respektiewelik die toon aangegee. In hierdie tyd het die Griekse studie versmal tot 'n studie van grammatika en tekskritiek.

In die twintigste eeu het B. A. van Groningen in Leiden 'n groot rol gespeel en heelwat S.A. geleerdes het onder sy hande deurgeloop. Onder hom is die Klassieke studie weer verruim.

Aan die Univèrsiteit van Groningen was meer estetiese en etiese belangstelling as grammatikale en tekskritiese spesialisasic.

Aan die Vrije Universiteit van Amsterdam was Latyn belangriker as Grieks en die Klassici van genoemde universiteit het nie 'n groot invloed op die studie van Grieks in Neder- 
land uitgeoefen nie. Die studie van Grieks aan die V.U. het nie groot klem op tekskritiek gelê nie, maar eerder die opvoedkundige waarde van die Klassieke onderrig nagestreef. Verder het die onderrig in Grieks aan die V.U. ook rekening gehou met die behoeftes van die teologie. Dit bly die Attiese dialek wat geleer word.

In die ses eeue van die Renaissance af, het die Christene nie die studie van Grieks teengestaan nie; teoloë moes almal die ou tale leer. Luther, Calvyn en alle groot teoloë het die nodigheid van goeie taalkennis van Grieks vir die verklaring van die N.T. besef. Die teoloë het egter ook nie 'n bepaalde karakter aan die studie van Grieks gegee of 'n bepaalde rigting aangedui nie. Hulle het die tradisie nagevolg. Die klassici daarenteen, en die opvoedkundiges, het Klassieke studie om die eties-estetiese redes voortgesit. Hierdie opvoedkundiges en klassici het ook die opleiding van die teoloë waargeneem. Wat Grieks betref, was die taalonderrig steeds toegespits op die Attiese literêre taal. Vele klassici was ò nie groot kerkmense nie òf selfs teen die kerke. Marx en Engels was bv. ook goed onderlê in die Klassieke.

Die Klassieke het die grootste deel van die skoolonderwys tot laat in die negentiende eeu uitgcmaak, toe dit verdring is deur die praktiese eise van die prakties-gerigte empiriese onderrig.

'n Vraagstuk wat gevolglik groot aandag verdien, is die vraag in hoeverre die Klassieke bygedra het tot die groei van die liberalisme in die Westerse denke, en meer in besonder hoe die skool, met sy groot klem op die Klassieke, hiertoe 'n bydrae gelewer het. Navorsing in die leerplanne van die verskillende skole uit verskillende tye behoort veel lig op hierdie agtergrond van die Westerse denkfoute te werp. Die invloed van die Klassieke was so groot dat selfs predikante, veral in Engeland, die Klassieke bewonder het as ' $n$ middel om die mens se gees te verhef tot edelheid en reinheid. Op grond van die leerstellings uit die skolastiek het die Rooms-Katolieke Kerk hierdie rigting bevorder (vgl. ook Baldry, p. 6). „Al ons humanistiese studie", sê Baldry, "het sy wortels in die Antieke" (p. 12).

In die oordrag van die klassieke humanisme na die moderne mens het die skoolonderwys seker nie die onbelangrikste rol gespeel nie.

6. Grieks in Suid-Afrika. 'n "Board of Examiners" is in 
1853 deur sir George Grey aan die Kaap ingestel. Die „Board of Examiners" het drie eksamens ingestel nl. die Eerste klas (gelykstaande aan M.A.), die Tweede klas (gelykstaande aan B.A.) en die Derde klas (gelykstaande aan matriek). Vir al drie hierdie eksamens was Grieks en Latyn verpligtend.

In 1873 is "The University of the Cape of Good Hope" met afhanklike kolleges gestig deur die "Higher Education Act”. Hiermee het die eksaminerende liggaam, nl. die „Board of Examiners" verval.

In navolging van Engelse universiteite het Grieks en Latyn 'n groot deel van die leerplanne vir die B.A.-graad in „Languages, Literature and History" uitgemaak; selfs vir die B.A.graad in "Mathematics" asook die B.A.graad in "Physical Science" was Grieks en Latyn verpligtend. Vir die M.A.-graad in "Languages, Literature and History" het Latyn en Grieks die hele leerplan gevorm.

$\mathrm{Na} 1883$ het die verpligting van Latyn en Grieks vir die B.A.-graad in "Mathematics" en "Physical Science" verval. Vir die "Intermediate B.A." tussen matriek en B.A. was Grieks opsioneel, maar vir die "B.A. Honours" was 'n kennis van Grieks en Latyn verpligtend.

Ook in S.A. het die beweging na die prakties-gerigte vakke dus die studie van die Klassieke verdring. In 1910 word ook Latyn opsioneel vir die "Intermediate B.A." en in 1913 word Latyn en Grieks vir die B.A.-graad onder die afdeling "Modern Languages" geklassifiseer.

In 1917 is al die kursusse vir die B.A.-graad in vier groepe verdeel: vir die eerste groep was Latyn en Grieks verpligtend; vir die tweede groep moes Latyn of Grieks geneem word; vir die derde groep was Latyn en Grieks opsioneel, en in die vierde groep is Latyn en Grieks nie genoem nie. Vir die „B.A. Honours" het die Klassieke ook opsioneel geword behalwe in die afdeling „Classics" (Beginsels en Met., p. 120). (Beginsels en metodes van die Hoër Onderwys, J. C. Coetzee en D. J. van Rooy).

In 1916 het Stellenbosch en Kaapstad selfstandige Universiteite gekry en in 1918 is die ander Kolleges van die „Univ. of the Cape of Good Hope" saamgesnoer in "Die Universiteit van Suid-Afrika". In 1921 is die Universiteit van die Witwatersrand en in 1930 die Universiteit van Pretoria uit hierdie groep afgestig. In 1921 is ook die Potchefstroomse Universiteitskollege vir C.H.O. as 'n kollege by die Universiteit van Suid- 
Afrika ingelyf.

Aan al hierdie universiteite en kolleges is Latyn en Grieks as verpligte vakke vir grade, ook in die Artium-rigting, gaandeweg verdring, totdat Latyn net vir regte en moontlik vir Frans en Engels aan sommige inrigtings, en Latyn en Grieks vir teologie verpligte vakke gebly het.

Die karakter van die Klassieke aan die S.A. Universiteite is geskoei op die Engelse of Hollandse tradisie: die Engelse tradisie veral aan die Engelse Universiteite en die Hollandse tradisie veral aan die Afrikaanse Universiteite. In Grieks is steeds gehou by die strewe na suiwer Attiese Grieks. Aan sommige universiteite bestaan nou egter ' $n$ kursus in Hellenistiese Grieks.

7. Grieks aan die P.U. vir C.H.O. In 1869 is die Teologiese Skool te Burgersdorp gestig deur die Gereformeerde Kerk, nie alleen vir die opleiding van predikante nie, maar ook vir onderwysers, ,ja ook jongelieden zonder een bestemd doel te hebben".

Die eerste twee dosente was ds. D. Postma en ds. J. L. Cachet. Ds. Postma het, behalwe die teologiese vakke, behartig: Latyn, Grieks, Hebreeus, Logika en Retoriek. Ds. Cachet het behartig: Hollandse taal en styl, Latyn vir jong klasse, Grieks (beginners), Hebreeus (beginners), Matesis, Fisika, Metafisika, Oorsig van die Algemene Geskiedenis, Griekse en Romeinse oudhede, Kerkgeskiedenis en Eksegetiek.

Die trivium logika, retoriek en Griekse en Latynse grammatika is dus ingesluit. Die Grieks was Attiese Grieks.

In 1876 word 'n prof. theologicus en 'n prof. litterarum benoem. Die vakke wat aan die literariese afdeling aangebied is, was 1. Hollands; 2. Latyn, Grieks, Hebreeus en Bybelse Chaldeeus; 3. Algemene Geskiedenis, Geografie en Mitologie; 4. Natuurkunde en 5. Logika en Metafisika. Hierin is studente so onderrig dat hulle die B.A.-eksamen kon aflê.

As Prof. Theol. is benoem ds. D. Postma en as Prof. Litt. mnr. P. Postma, seun van ds. D. Postma. Hy het sy B.A. aan Gill College, Somerset-Oos, behaal.

Van 1879 af is matriek as toelatingskwalifikasie vereis.

In 1880 bedank prof. P. Postma as dosent omdat hy 'n beroep as predikant aanvaar het en mnr. M. Postma, met 'n M.A.graad in Klassieke Tale, word benoem as Prof. Litterarum. Hy het die literêre afdeling herorganiseer soos volg: A. Hollands; B. Latyn; C. Grieks; D. Mitologie; E. Logika en Reto- 
riek; F. Algemene Geskiedenis.

Die Griekse leerplan het beslaan:

1. Poësie - een Attiese tragedie en een boek uit die Odyssea of Ilias van Homeros.

2. Prosa - 'n boek van 'n geskiedskrywer uit die Klassieke tyd.

3. Opstelle in Grieks.

Die leergang sluit dus die vakke van die ou trivium in. Uit die leerplan blyk duidelik die Hollandse karakter van Grieks aan die Teologiese Skool en wel die V.U. se tradisie, waarin die groot klem nie op tekskritiek geval het nie.

In 1889 neem ook prof. M. Postma 'n beroep aan as predikant en sy broer, mnr. S. Postma (B.A.), word in sy plek aangewys. In 1894 verval Mitologie en Retoriek as vakke aan die Teologiese Skool.

In 1897 neem prof. S. Postma ook 'n beroep aan en mnr. P. C. Snyman word benoem as professor in sy plek met mnr. J. A. du. Plessis as tweede professor.

In 1904 word besluit om die Teologiese Skool oor te plaas na Potchefstroom en mnr. F. Postma word benoem as Prof. Litterarum in die plek van prof. P. Snyman wat ook 'n beroep aangeneem het.

Prof. F. Postma was 'n klassikus van naam en het die graad D.Litt. met lof behaal met 'n proefskrif „De Numine Divino quid senserit Vergilius" wat hy in Latyn geskryf het.

In 1945/46 was prof. L. J. du Plessis hoof van die departement Klassieke. In 1947 is die departement geskei in twee departemente, nl. Grieks en Latyn onderskeidelik. Die eerste hoof van die dept. Grieks was my onmiddellike voorganger, prof. A. Postma. By hom was die volgorde andersom, hy was nl. eers predikant en daarna professor.

Reeds so vroeg as 1913 het die V.U. van Amsterdam sowel die propedeutiese studie as die kandidaatseksamen in die teologie van hierdie Teologiese Skool erken. Hieruit blyk nie alleen dat die standaard hoog was nie, maar ook dat die V.U. tevrede was met die gees en karakter van die studie. Die karakter van Grieks het ooreengekom met dié van die V.U.; die dosente van die Skool het immers hul opleiding aan die V.U. te danke gehad.

In 1910 skei die teologiese en literêre afdelings van die skool. Van 1921 af, met die inkorporering van die P.U.K. vir C.H.O. by die Universiteit van Suid-Afrika, is die eksamens 
van die Universiteit van Suid-Afrika afgelê.

Uit 'n vergelyking van die leerplanne van die Universiteit van Suid-Afrika en die P.U.K. vir C.H.O. blyk dat daar heelwat ooreenkoms was, trouens die Hollandse en Engelse Klassieke tradisie het nie baie van mekaar verskil nie.

Albei het wat grammatikale onderrig betref, suiwer Atties nagestreef. Die werke van Homeros, die Atheense geskiedskrywers, redenaars en filosowe is gelees en die geskiedenis van die Grieke tot 323 v.C., die jaar van Alexander die Grote se dood, is geleer. Van die begin af, d.w.s. van die stigting van die Teologiese Skool te Burgersdorp, is steeds voorsiening gemaak t.o.v. teologiese studente vir die lees van een boek uit die N.T. i.p.v. 'n boek van Herodotos uit die vyfde eeu v.C., of die werk van 'n Patristiese skrywer (kerkvaders) i.p.v. 'n boek van Demosthenes uit die vierde eeu v.C.

Grammatikale onderwys was steeds 'n onderrig van Atties en die bypassende leeswerk is steeds hoofsaaklik gekies uit die Atheense skrywers, hoewel Homeros en Herodotus se werke volgens tradisie gelees is.

Hierdie is min of meer nog die toestand vandag in S.A. en ook aan hierdie Universiteit.

Die opleiding wat hier en ook op vele ander plekke gebied word, verskil van die Atheense, Alexandrynse, Romeinse en humanistiese aanbiedinge daarin dat aan die student oorgedra word „dat ons lewensinspirasie en model van ons persoonlike en volkslewe nie by die helde van Athene" gesoek moet word nie, "maar by Christus en die helde van die Heilige Skrif" (Beginsels en Met., p. 131).

Hierdie is wat die gelowige klassikus aan studente in die Klassieke voorhou. „Die doel van die Klassieke wetenskap is om so volledig en wesensgetrou as enigsins moontlik, die beeld van die Klassieke oudheid te rekonstrueer, en om te probeer deurdring tot die wese van die Klassieke wêreld, in sy samehang en besonderhede om tot ' $n$ wetenskaplike verklaring daarvan te geraak" (Beginsels en Metodes, p. 120). Die wetenskaplike verklaring van die Klassieke aan hierdie Universiteit word gedoen "In U Lig".

In die geskiedenis van die P.U. vir C.H.O., van sy ontstaan af met die Teologiese Skool in 1869 te Burgersdorp, het die meeste studente Grieks geleer met die doel om predikant te word. Voor die stigting van die P.U.K. vir C.H.O. in 1921 het waarskynlik meer studente wat nie predikante wou word 
nie as daarna Grieks geleer omdat Klassieke studie en opvoeding toe nog na die patroon van Klassieke onderrig in Engeland en Holland feitlik verpligtend was vir elke B.A.-student.

$\mathrm{Na} 1921$ was so te sê alle studente wat Grieks geleer het van plan om predikant te word. Van 1952 af, dit is sedert ek aan die Universiteit benoem is, was byna elke student wat vir Grieks ingeskryf het van plan om predikant te word. Van hierdie studente het 'n aantal deur die jare van plan verander nadat hulle Grieks selfs as hoofvak gekies en tot die derde jaar deurgedring het. Van hierdie studente wat Grieks gevolg het tot die derde jaar en nie predikant geword het nie, het een aangegaan met die nagraadse studie en M.A. in Grieks behaal, terwyl heelwat studente wat wel predikant geword het, aangegaan het met Honns.-B.A. en een tans met die M.A.-studie in Grieks besig is.

Slegs enkele studente na 1952 het Grieks kom volg slegs uit belangstelling vir die Klassieke of as hulpvak by moderne tale of wysbegeerte. Soos reeds gesê, het dit wel voorgekom dat studente wat Grieks geneem het van plan verander en ' $n$ ander rigting, bv. wysbegeerte of ander tale, gaan volg het. Een van ons studente van voor 1952, wat oorspronklik teologie beoog het, het 'n paar jaar gelede hier sy D.Litt. in Grieks verwerf.

In die lig van hierdie feite kan die vraag nou gestel word of die doel en plek van Grieks aan ons Universiteit nog suiwer die doel van die ou tradisionele Klassieke, Attiese geleerdheid kan wees.

Moet die aanbieding van Grieks nie by die eise en doel van diegene wat daarvoor inskryf, aangepas word nie?

Dit sou seker nie help om suiwer Klassieke aan te bied as niemand daarvoor wil inskryf nie, al word dit ook „In U lig" aangebied. Dit is nie die doel van hierdie betoog om 'n uitgewerkte leergang daar te stel nie, maar om hooflyne aan te toon.

In die eerste plek moet vandag aanvaar word dat Grieks in ons land prakties nie meer ' $n$ skoolvak is nie, maar 'n universiteitsvak. ,

Die doel van die voornemende teologiese student met die studie van Grieks is om die N.T., wat in Koinê Grieks geskryf en oorgelewer is, te kan lees en te verklaar.

Hiervoor moet die student 'n goeie kennis van die taal van die N.T. hê, nl. die Koinê, nie Atties nie, wat vier tot ses eeue voor die tyd van die N.T. as literêre taal gebruik is. 
'n Taal moet nie diachronies aangeleer word nie maar wel sinchronies; ' $n$ woordbetekenis en gebruik; 'n bepaalde sinskonstruksie en taalgebruik wat in die werke van Homerus 7 eeue v.C. en Klassieke Attiese werke vier tot vyf eeue v.C. voorkom, kan tog nie as maatstaf en verklaringsgrond vir dié woordbetekenis en gebruik in die Koinê, d.w.s. die spreektaal uit die tyd van Christus, dien nie.

In die geval van moderne tale soos bv. Duits, Nederlands, Engels, Afrikaans word die taalgebruike van die betrokke taal sinchronies bestudeer, d.w.s. in die omlysting van hulle tyd, en soos met die studie gevorder word, word ook aandag gegee aan die vroeëre vorme soos Middelhoogduits, Hooghollands, Oud-Engels en -Nederlands, respektiewelik of wat die geval ook al mag wees.

Suiwer uit taalkundige oorweginge behoort die voornemende teologiese student wat Grieks moet neem, direk te begin met Koinê Grieks. Vroeër het die nodige grammatikaboeke hiervoor ontbreek, maar vandag is daar genoeg grammatikaboeke oor die Koinê vir hierdie doel. Ook die bypassende leeswerk by die studie van die Koinê ontbreek nie. Al die boeke van die N.T., die Apokriewe boeke, sekere boeke van die Apostoliese Vaders asook digters en lesbes 'n magdom van opgegrawe papyri-materiaal is beskikbaar.

Ter wille van die eise van die taalkunde behoort, dan, soos die student vorder, ook diachroniese uitbreiding van die taalstudie gedoen te word: so behoort die student die hoofelemente waaruit die Koinê ontwikkel het, te bestudeer, nl. Atties en Ionies. Maar ook die Patristiese Grieks of taal van die latere kerkvaders, wat 'n verdere ontwikkeling is, behoort bestudeer te word.

Bypassende leeswerk hierby is natuurlik die bekende skrywers, nl. by die Attiese dialek die Klassieke skrywers en by die Patristiese Grieks die, minder geleesde, kerkvaders.

Sover is hier nog net gehandel oor die taalstudie, wat die hoofsaak is vir die beginner. Die voornemende teologiese student moet egter ook die kultuurhistoriese agtergrond van die N.T. leer. Die direkte agtergrond is natuurlik die geskiedenis van Israel, wat val onder die departement Semitiese Tale. Maar die student moet ook die nie-Bybelse agtergrond, nl. hoofsaaklik die Griekse, Hellenistiese en Romeinse kulture leer. Die Romeinse kultuur val onder die dept. Latyn.

Die studie van Grieks as voorbereiding vir die teologiese 
studie moet gevolglik, behalwe die taalkunde, ook die hele kulturele veld dek, nl. Griekse geskiedenis en geografie, godsdiens en mitologie, kuns, letterkunde, wetenskappe waaronder die Griekse wysbegeerte, geskiedskrywing, logika en retoriek asook die fisiese of natuur- en biologiese wetenskappe, in kort ciie hele Griekse lewe, al sou sekere dele ook as onderdeel by ander vakke aandag ontvang. Hierdie ensiklopediese tipe geleerdheid, wat ook deur die Duitse Altertumswissenschaft nagestreef is, word onder verskillende hulpdissiplines bestudeer.

Maar in totaal moet hierdie stof ,in U lig" verklaar en waardeer word. So moet bv. aangetoon word hoe die mite ' $n$ vervalsing van openbaringswaarhede is en dat daar selfs ' $n$ ontwikkelingslyn van mitegeskiedenis teenoor die openbaringsgeskiedenis bestaan. So moet aangetoon word hoe die ontwikkeling van die rasionele wetenskapsideaal die verhale van die Griekse gode eers as mites bestempel het en daarna die ou geloof van mites gesuiwer het, totdat nog net die rasioneel verklaarbare feite as waarheid oorgebly het. Die ontwikkelingsgang van Mythos na Logos moet aangetoon word. Die proses dus van ontmitologisering en rasionalisering wat daarop uitloop dat die Logos, die Rede, die verstand, selfs wêreldlogos of wêreldverstand die enigste verklaringsgrond van alles gesien word.

Teen hierdie agtergrond kan bv. die woorde van Johannes in sy Evangelie verstaan word waar hy sê ,in die begin was die Logos en die Logos was God". Selfs die woorde van Christus in die Evangelie van Johannes, hoofstuk 14, sny diep teen hierdie agtergrond as Hy sê: „Ek sal aan julle 'n ander trooster stuur", nl. die Gees van die Waarheid wat die wêreld nie kan ontvang nie, omdat dit Hom nie sien nie en Hom nie ken nie. Die waarheid wat die wêreld ken is die waarheid waartoe die logos, die rede, lei.

Hierdie en ander dieptes is die beloning van die student wat die Grieks-heidense agtergrond van die N.T. wil leer, en dit is tewens die taak van die dosent om hierdie perspektief vir dic student te open.

Hiervoor moet die student dan ook breed lees: uit die werke van Homeros en ander digters, uit die werke van geskiedskrywers, redenaars, wysgere en ander oorgelewerde asook oorgeblewe geskrifte, van Homeros af tot by die kerkvaders. 
Hierby kry die student dan nog 'n verdere beloning op die koop toe, nl. die opvoedkundige, estetiese en etiese waardes waarvoor die Klassieke deur die eeue beoefen en bestudeer is.

Die tyd toe die Klassieke bestudeer is vir suiwer genot van die skoonheid van die lettere is ook reeds lankal verby. Die standaard wat tot by die derde jaar behaal kan word, is nog nie so gevorder dat 'n student die skoonheid van die taal kan waardeer nie. Daarby moet in gedagte gehou word dat die Griekse versmaat eintlik musiekmaat is, en omdat die musiek van die gedigte nie oorgelewer is nie, kan nooit tot volle waardering van hierdie veelgesogte genot gekom word nie.

Dit is verder verstaanbaar dat in die beperkte tyd tot beskikking van die student met nog 'n gebrekkige taalkennis, hy nie soveel van die Griekse werke, sowel Klassiek as van die Koinê en Patristiese Grieks, kan lees dat hy die Griekse kultuur daaruit kan leer ken nie. Hiervoor behoort vergoed te word deur gebruik te maak van vertalings, waarvan in Engels, Hollands, Duits en Frans feitlik alle Griekse werke bekombaar is. Afrikaanse vertalings bly egter skaars. Hier bestaan nog 'n groot behoefte.

Opsommend mag weer herhaal word dat Grieks aan ons Universiteit hoofsaaklik in diens van die teologie staan, dat by hierdie eise aangepas behoort te word, dat die grammatika van die Koinê vir die teologiese student aangebied moet word terwyl Atties vir die student wat die Klassieke wil neem, aangebied moet word;

dat die teologiese student, wat also met die Koinê begin, ook diachronies moet uitbrei na die Attiese en Patristiese Grieks. Hierby moet die Kultuur-historiese agtergrond gedoen word om die heidense agtergrond van die Christelike teologie bloot te lê.

Die nagraadse student moet ook 'n geskiedenis van die Klassieke geleerdheid doen. Daarmee samehangend en daaruit voortvloeiend moet die metodologie van die Klassieke studie gedoen word.

Al hierdie dinge moet nie net as feite aangetoon word nie, maar daar moet duidelik gewys word hoe die hele vak lyk „In U Lig".

J. H. Grobler. 